\title{
Variable Rates of Phosphorous Application Influenced Phenological Traits of Green Gram (Vignaradiata L.)
}

\author{
Imran ${ }^{1 *}$, Zada $\mathrm{H}^{2}$, Naveed $\mathrm{S}^{3}$, Khattak $\mathrm{I}^{4}$ and Ahmad $\mathrm{S}^{5}$ \\ 1Department of Agronomy and CCC the University of Agriculture, Pakistan \\ ${ }^{2}$ Agriculture Officer, Agriculture Extension department Swat, Pakistan \\ ${ }^{3}$ Government Girls Degree College Karak, Pakistan \\ ${ }^{4}$ Department of Agronomy, the University of Agriculture Peshawar, Pakistan \\ ${ }^{5}$ Department of Plant breading and genetics, The University of Agriculture, Pakistan
}

\section{Research Article}

Volume 1 Issue 3

Received Date: September 24, 2016

Published Date: October 28, 2016

*Corresponding author: Imran, Department of Agronomy and CCC the University of Agriculture, Pakistan, Email: imranagrarian@aup.edu.pk

\section{Abstract}

Present study was established in a randomized complete block design with three replications at Agriculture Extension Demonstration plot Matta Circle Swat Pakistan, in summer 2014. Five levels of phosphorous $(20,40,60,80 \mathrm{and} 100 \mathrm{~kg}$ $\mathrm{ha}^{-1}$ ) with one control in the form of single super phosphate (SSP) and three cultivars of mungbean (SWAT-I, SWAT-II and NM-54) were used during the experiment. Results revealed that weeds density and phenological traits of mungbean varied with $\mathrm{P}_{2} \mathrm{O}_{5}$ application. A linear increase in weeds density was observed with increase in $\mathrm{P}_{2} \mathrm{O}_{5}$ levels. Fewer days to flowering (40 days) were observed in plots received $P$ at the rate of 80 and $100 \mathrm{~kg}^{-1}$ hallowed by $60,40,20$ and $0 \mathrm{~kg} P$ ha $^{-1}$, while more (44 days) were recorded in control plots. In case of varieties late flowering (42 days) was observed in variety SWAT I followed by SWAT-II, while early flowering (41 days) was recorded incultivar NM-54. Minimum days (48 days) to pods formation was noticed in $\mathrm{P}_{2} \mathrm{O}_{5}$ at the rate of 80 and $100 \mathrm{~kg} \mathrm{ha}^{-1}$, while more days (52 days) to pod formation were recorded in control plots. In case of varieties NM-54 took less days (49 days) while SWAT-I were statistically at par. Among the varieties SWAT-I produced maximum biological yield (3551 kg ha-1) followed by SWAT-II (3440 kg ha-1) and NM-54 (3317 kg ha-1) respectively.

Keywords: Mungbean (Vignaradiata L.); Phenological traits; Phosphorous

\section{Introduction}

Mungbean (Vignaradiata L.), belong to family leguminaseae. It is an indeterminate, self-pollinated crop of the short duration grown in kharif season. It is also known as king of the pulses. Mungbean contains 1-3\% fats, 50.4\% Carbohydrates, 3.5-4.5\% fibers and 5.5\% ash, while calcium and phosphorus are 132 and $367 \mathrm{mg}$ per 100 grams of seed, respectively [1-4]. Pulses contain important amino acids known as lysine which is frequently available in mungbean crop [4]. This essential amino acids is deficient in most of cereal grains and therefore known as poor man meat $[5,6]$. The production of mungbean is very low due to poor management of cultural practices and got less attention of the farmers. Therefore a small area under mungbean cultivation is practiced in Pakistan which ranges up to 137.4 hectare with an average production 76.2 tons per hectare during 


\section{Open Access Journal of Agricultural Research}

2011. In Khyber Pakhtunkhwa mungbean was grown on an area of 8.5 hectare within average yield of $600 \mathrm{~kg} \mathrm{ha}^{-1}$ which is very low as compared to advanced countries [7]. The main reasons for low yield in Pakistan are poor crop management practices and less soil fertility which do not fulfill crop nutrients requirements. Production of mungbean can be optimize by proper nutrients management and good soil health. Soil health can be sustain with addition of organic matter, less application of chemicals with proper management of weeds. Weeds are exhaustive in nature, showing aggression in term of nutrients and water uptake and compete with economic crop for other essential yield contributing traits. So to overcome on these constraints and to enhance production of the economic crop, optimum use of fertilizers should be treated with optimum eradication and suppression of weeds.

In this contents Phosphorus plays a remarkable role in the formation and translocation of carbohydrates, assimilation of photosynthates, and development of roots with dense growth, crop maturation and resistance to disease [8]. Increases in the yield of different crops have been noticed with the application of macronutrient while poor performance of phosphorus fertilizer leading to depressed the productivity of the crops $[2,3,6,9,10]$. Applications of Phosphatic fertilizer to plants improve root development, which increased uptake of other nutrients and water to the growing parts of the plants. Photosynthates and more dry matter accumulation increased with phosphorus utilization by the plants. It has been reported that phosphorus increases number of pods plant $^{-1}, 1000$ seed weight, seed yield, number of seeds pod $^{-1}$ and total biomass in mungbean [1,6,11-17]. In exploiting and success of crop productivity varieties play an important role to boost up potentiality of the crop and produced greater yield. High yielding varieties and suitable sowing time are the most important factors affecting the yield. It is necessary to increase the production through varietal development and proper management practices.

Keeping in view the importance of phosphorus and mungbean varieties, present study was design to study the effect of phosphorus levels for improving phenological, morphological traits, yield and yield contributing parameters of mungbean cultivars.

\section{Materials and Methods}

The response of mungbean cultivars to various phosphorous levels and its impact on weeds frequency and density was investigated at Agriculture Extension Demonstration Plot Matta Circle Swat Pakistan, in summer 2014. The experiment was laid out in randomized complete block design having three replications. Each experimental unit was $3 \times 3 \mathrm{~m}^{2}$ having 10 rows. Row to row and plant to plant distance were 30 and $10 \mathrm{~cm}$ respectively. Three mungbean varieties (SWAT I, SWAT II and NM-54) and five levels of phosphorus (20, $40,60,80$ and $100 \mathrm{~kg} \mathrm{ha}^{-1}$ ) with one control plot were used during the experiment. Phosphorus formulated treatments in the form of SSP $\left(15.5 \% \mathrm{P}_{2} \mathrm{O}_{5}\right)$ and recommended starter dose of Nitrogen in the form of urea (25 $\mathrm{kg} \mathrm{ha}^{-1}$ ) were applied at sowing time.

All other agronomic practices like irrigation, insect pest control and hoeing after calculation of weeds frequency was carried out for a successful crop production and attainable yield. Data were statistically analyzed through relevant procedure according to the randomized complete block design (RCBD) using $F$ test for least significant difference for mean comparison.

\section{Results and Discussion}

\section{Days to first flowering}

Analysis of data showed that phosphorus (P) levels and varieties (V) significantly affected days to first flowering. The interaction between $\mathrm{P} \times \mathrm{V}$ showed no significant effect on days to flowering. Increase in $\mathrm{P}$ level causes early flowering in all the mungbean varieties. Fewer days to flowering (40 days) were observed in plots received $\mathrm{P}$ at the rate of 80 and $100 \mathrm{~kg} \mathrm{ha}^{-1}$ followed by $60,40,20$ and $0 \mathrm{~kg} \mathrm{P}$ ha-1, while more (44 days) were recorded in control plots. In case of varieties late flowering (42 days) was observed in variety SWAT-I followed by SWAT-II, while early flowering (41 days) was recorded by variety NM-54. Phosphorus levels and varieties had significantly affected days to first flowering and pod formation. Delay in flowering and pod formation was occurred with decrease in P level. Control plots took maximum days to first flowering and pod formation. These results are in line with Khan et al. [1-3,13-20]. Who reported that increased in phosphorous caused early first flowering and pod formation. Mungbean variety had also significant effect on days to first flowering and pod formation. Variety SWAT I and SWAT II delayed first flowering and pod formation as compare to NM-54 (Figure 1). The variation of phenology among the varieties might be due to their genetic makeup. These results are in line with Yadi et al. [2,3,6] who reported different duration for phonological events for various varieties. 


\section{Open Access Journal of Agricultural Research}

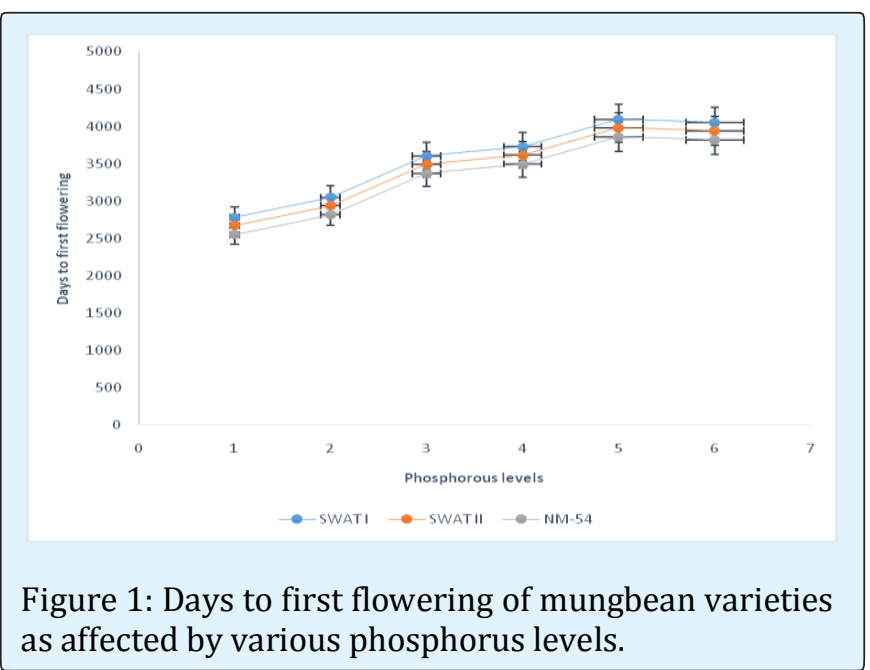

\section{Days to first pod formation}

Results revealed that phosphorus (P) levels and mungbean varieties (V) significantly affected days to first pod formation, while interaction between $\mathrm{P} \times \mathrm{V}$ nonsignificantly affected days to pod formation. Mean value of the data showed that plots applied $\mathrm{P}$ at the rate of 80 and $100 \mathrm{~kg} \mathrm{ha}^{-1}$ took less days (48 days) to pod formation, while more days to (52 days) to pod formation were recorded in plots received no phosphorus. In case of varieties NM-54 took fewer days (49 days) while SWAT I was statistically at par by taking ( 50 days) to pod formation. Phosphorus levels and varieties had significantly affected days to first flowering and pod formation. Delay in flowering and pod formation was occurred with decrease in $\mathrm{P}$ level. Control plots took maximum days to first flowering and pod formation (Figure 2). These results are in line with Khalil et al. who reported that increased in phosphorous caused early first flowering and pod formation. Mungbean variety had also significant effect on days to first flowering and pod formation. Variety SWAT I and SWAT II delayed first flowering and pod formation as compare to NM-54. The variation of phenology among the varieties might be due to their genetic makeup. These results are in line with $[2,3,21]$ who reported different duration for phonological events for various varieties $[1,13-17]$.

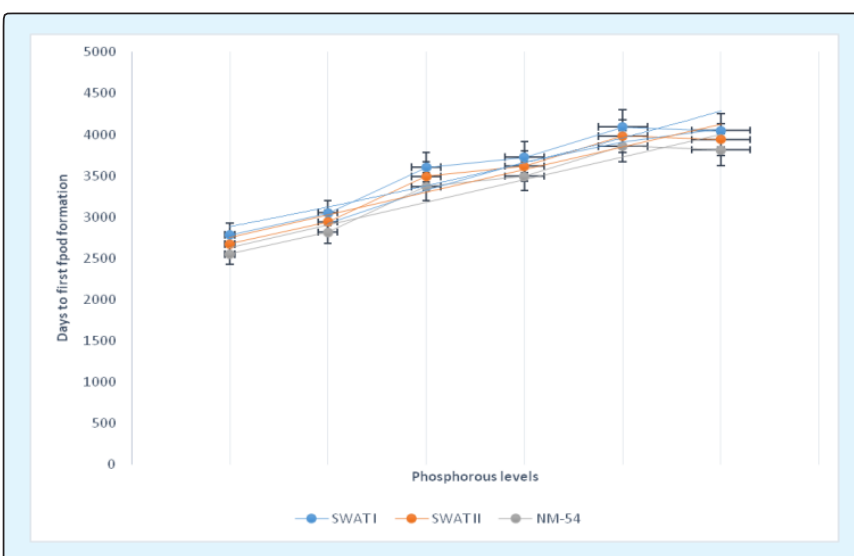

Figure 2: Days to first pod formation of mungbean varieties as affected by various phosphorus levels.

\section{Plant height (cm)}

Phosphorus (P) levels and mungbean varieties (V) significantly affected plant height while the interaction between $\mathrm{P} \times \mathrm{V}$ non-significantly affected plant height. Plots applied with $60 \mathrm{~kg} \mathrm{P} \mathrm{ha}^{-1}$ produced taller plants by attaining $(73.9 \mathrm{~cm})$ height. Phosphorus applied at the rate of 80 and $100 \mathrm{~kg} \mathrm{ha}^{-1}$ was statistically at par. while shorter plant height $(57.3 \mathrm{~cm})$ was recorded in control plots. Among the varieties SWAT I attained plant height $(69.2 \mathrm{~cm})$ while shorter plant height $(66.9 \mathrm{~cm})$ was observed in variety NM-54. Phosphorus levels and varieties had significantly affected plant height. Plots treated with $60 \mathrm{~kg} \mathrm{P}^{-1}$ produced taller plants height, being at par with 80 and $100 \mathrm{~kg} \mathrm{P} \mathrm{ha-1.} \mathrm{While} \mathrm{shorter}$ plants height was recorded in control plots (Figure 3). Malik et al [22] reported that increase in p levels might be decreased plant height; contradiction might be due to the change in climatic and experimental site conditions or genetic makeup of the different varieties [1,13-17,23-26].

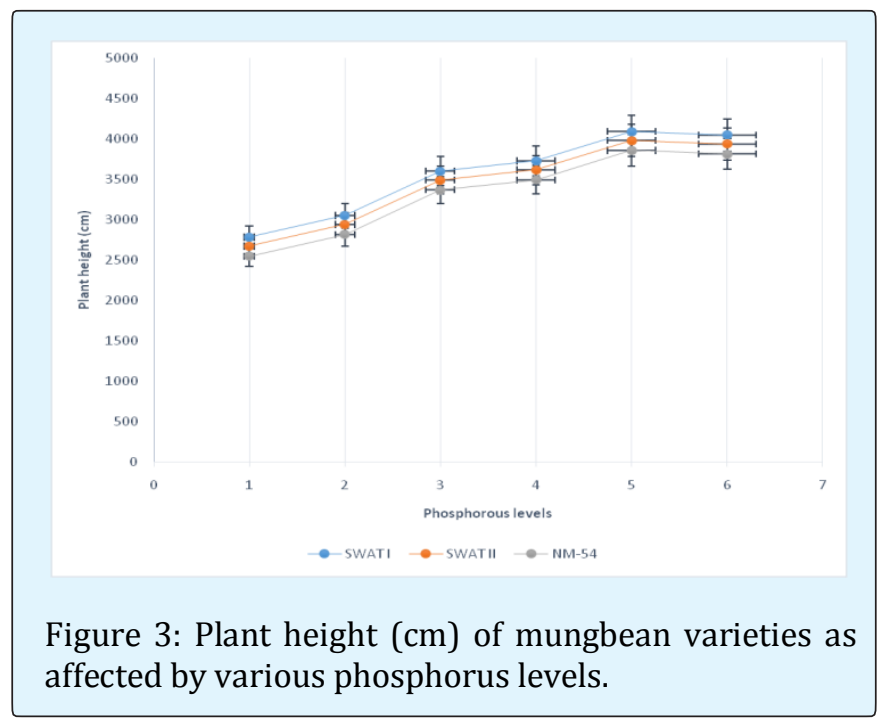




\section{Open Access Journal of Agricultural Research}

\section{Conclusion}

It was concluded that phenological traits of mungbean varied with $\mathrm{P}_{2} \mathrm{O}_{5}$ application. In case of phenological traits of mungbean, elevated traits was noticed at the rate of 80 kg $\mathrm{P}_{2} \mathrm{O}_{5}$ ha $^{-1}$. In case of mungbean cultivars SWAT-I ranked first in all attributes contributing to yield. On the basis of above findings it is recommended that SWAT-I cultivar should be treated with $80 \mathrm{~kg} \mathrm{P2O5} \mathrm{ha-1}$ for higher yield under the agro-ecological condition of Malakand division.

\section{References}

1. Frauque A, Haraguchi T, Hirota O, Rahman MA (2000) Growth analysis, yield, and canopy structure in maize, mungbean intercropping. Bu Inst of Trop Agric 23: 61-69.

2. Yadi R (2012) Role of zinc fertilizer on grain yield and some qualities parameters in iranian rice genotypes. Annals of Biological Research 3(9): 4519-4527.

3. Imran (2015) Effect of germination on proximate composition of two maize cultivars. J Bio Agric Health Care 5(3): 123-128.

4. Imran, Khan AA, Inam I, Ahmad F (2016) Yield, and yield attributes of Mungbean (Vigna radiata L) cultivars as affected by phosphorous levels under different tillage systems. Cogent Food \& Agriculture 2: 1151982.

5. Malik BA (1994) Grain legume. In: Bashir E, Bantel R (Eds.), Crop Production National Book Foundation, Islamabad, Pakistan. pp. 277-328.

6. Imran, Khan AA, Khan IU, Naveed S (2016) Weeds density and late sown maize productivity influenced by compost application and seed rates under temperate environment. Pak J Weed Sci Res 22(1): 169-181.

7. MINFA (2011) Agriculture statistic of Pakistan, Ministry of food, agriculture and Livestock, Govt. of Pakistan, Islamabad.

8. Arya MPS, Kalara GS (1988) Effect of phosphorus doses on the growth, yield and quality of summer mungbean and soil nitrogen. Ind J Agri Res 32(3): 2330.
9. Hossain MA, Hamid A (2007) Influence of $N$ and $P$ fertilizer application on root growth, leaf photosynthesis and yield performance of groundnut. Bang J Agri Res 32(3): 369-374.

10. Hossain MB, Rahman MW, Rahman MN, Anwar AHMN, Hossen AKMM (2010) Effects of water stress on yield attributes and yield of different Mungbean genotypes. Int J Sustain Crop Prod 5(1): 19-24.

11. Mitra S, Rhattacharya SK, Datta M, Banik S (1999) Effect of variety, rock phosphate and phosphate solubilizing bacteria on growth and yield of green gram in acid soils of Tripura. Envi. Ecno.17: 926-930.

12. Ayub M, Tanveer A, Choudhry MA, Amin MMZ, Murtaza G (1999) Growth and yield response of mungbean (Vigna radiata $L$.) cultivars at varying levels of nitrogen. Pak J Bio Sci 2(4): 1378-1380.

13. Dewangan MK, Pandey N, Tripathy RS (1992) Effect of spacing, irrigation and phosphorus on NP concentration and protein yield of summer green gram. Annals of Agri Res 13(3): 280-281.

14. Hussain F, Malik AU, Haji MA, Malghani AL (2011) Growth and yield response of two cultivars of mungbean (Vignaradiata L.) to different potassium levels. J. of Ani \& Pl Sci 21(3): 622-625.

15. Hussain TA (1994) Effect of NPK application on the growth and yield of mungbean (Vignaradiata L.). Agron 37(3): 549-551.

16. Kumar R, Singh YV, Singh S, Latare AM, Mishra PK, et al. (2012) Effect of phosphorus and sulphur nutrition on yield attributes, yield of mungbean (Vignaradiata L. Wilczek). J of Chem \& Pharm Res 4(5): 2571-2573.

17. Shahid I, Khan HZ, Shaheen H (2012) Growth and yield responses of mungbean (Vignaradiata L.) to different levels of phosphorus application under different tillage systems. Int J Agric Appl Sci (4):1.

18. Khan MA, Baloch MS, Taj, Gandapur (1999) Effect of phosphorus on the growth and yield of mungbean. Pak J Bio sci 2(3): 667-669.

19. Khan MA, Aslam M, Sultan T, Mahmood IA (2002) Response of phosphorus application on growth and yield of inoculated and un-inoculated mungbean (Vigna radiate L.). Int J of Agri \& Bio 523(4): 15608530. 


\section{Open Access Journal of Agricultural Research}

20. Imran, Khan AA (2015) Grain Yield and Phenology of Maize Cultivars Influenced by Various Phosphorus Sources. J Food Sci and Q Mang 37: 74-78.

21. Imran (2015) Influence of hydrated calcium sulphate $(\mathrm{CaSO4.2H2O})$ and nitrogen levels on water infiltration rate and maize varieties productivity in rainfed area of swat, pakistan. J Chem Res 7(3): 1520.

22. Malik MA, Hussain S, Warraich EA, Habib A, Ullah S (2002) Effect of seed inoculation and phosphorus application on growth, seed yield and quality of mungbean (Vigna radiata L.) CV. NM-98. Int J Agri Bio 4(4): 515-516.

23. Imran, Hussain I, Khattak I, Ur Rehman A, Ahamd F, et al. (2015) Roots nodulation, yield and yield contributing parameters of mungbean cultivars as influenced by different Phosphorous level in SwatPakistan. Pure and Applied Biology. Pure Appl Biol 4(4): 557-567.
24. Imran, Khan AA (2015) Influence of Compost Application and Seed Rates on Production Potential of Late Sown Maize on High Elevation in Swat -Pakistan. J Environ Sc 5(5): 36-40.

25. Sharer MS, Ayub M, Chaudhry MA, Rana MA, Amin MMZ (1999) Growth and yield response of mungbean (Vigna radiate L.) to various levels of phosphorus. Pak J Bio Sci 2(4): 1385-1386.

26. Statistix, statistix for windows analytical softwares, version 8.0, USA .2005. 